\title{
L-band Synthetic Aperture Radar: Current and future applications to Earth sciences
}

\author{
Yosuke Aoki ${ }^{*}$, Masato Furuya ${ }^{2}$, Francesco De Zan ${ }^{3}$, Marie-Pierre Doin ${ }^{4}$, Michael Eineder ${ }^{3}$, Masato Ohki ${ }^{5}$ \\ and Tim J. Wright ${ }^{6}$
}

Synthetic Aperture Radar (SAR) has been around for more than 40 years. The first civilian-use SAR satellite was SeaSat, launched by National Aeronautics Space Administration (NASA) in 1978 to monitor Earth's oceans. In early 1990s, we realized that SAR Interferometry (InSAR) is a powerful tool in delineating Earth's topography and deformation (e.g., Massonnet et al. 1993) because SAR can image broad areas with a high spatial resolution on the order of $10 \mathrm{~m}$ or less without a requirement of ground-based instruments. The advantage of SAR as a powerful imaging tool is also because it works day and night regardless of clouds.

SAR images taken from L-band satellites complement satellites at shorter wavelengths such as $\mathrm{C}$ - and X-bands. $\mathrm{L}$-band SAR has lower resolution than $\mathrm{C}$ - and $\mathrm{X}$-band images but are more coherent over time, especially in vegetated regions. L-band SAR data are typically easier to unwrap because of higher coherence and fewer fringes, but more susceptible to ionospheric effects.

L-band SAR satellites for InSAR include JERS-1 (19921998), ALOS (2006-2011), ALOS-2 (2014-present), and SAOCOM-1 (2017-present), which have a recurrence time of order a few weeks. Such recurrence times do not allow monitoring with high temporal resolution. However, after the launch of ALOS-4, NISAR, and Tandem-L in the next few years, we will be able to monitor Earth's surface every few days with L-band SAR. Therefore, the time is ripe to review what we have learned from previous and ongoing L-band missions, either spaceborne

\footnotetext{
*Correspondence: yaoki@eri.u-tokyo.ac.jp

${ }^{1}$ Earthquake Research Institute, The University of Tokyo, Tokyo, Japan Full list of author information is available at the end of the article
}

or airborne and what we expect to learn from future missions.

This special issue consists of 11 papers on various topics, including earthquake and volcano deformation, land subsidence, landslide, and permafrost.

SAR images revealed that an earthquake rupture is almost always more complicated than a shear failure on a planar fault. SAR images have demonstrated that an earthquake rupture accompanies off-fault cracks and lineaments. Fujiwara et al. (2020) reviewed the observations of such secondary features associated with several onshore earthquakes in the last 25 years. The geometry of the faults on which triggered shallow slip occurs is variable; some faults are parallel to the main fault, and some are oblique or perpendicular to the main fault. However, they found some common features that tend to occur on pre-existing weakness. Therefore, a large earthquake in the future would also trigger shallow slips at the same location.

Hashimoto (2020) and Ishitsuka et al. (2020) investigated the 2016 Kumamoto earthquake $\left(M_{\mathrm{w}}=7.0\right)$. Hashimoto (2020) investigated the first two years of postseismic deformation from ALOS-2 images. He noticed that the L-band SAR images are coherent even if image pairs are separated for 2 years. He also noticed that some images are susceptible to ionospheric perturbations. The observed deformation field is complex; the time constant of displacement decay varies between 30 to 600 days in different locations, indicating that the observed deformation results from multiple origins. Afterslip with a mixed right-lateral normal faulting mechanism explains much of the observed deformation field, but the afterslip cannot explain observed deformation in some areas (Table 1). 
Table 1 List of SAR missions

\begin{tabular}{|c|c|c|c|}
\hline Satellite & Band & Agency & Period \\
\hline Seasat & $L$ & US DoD & 1978 \\
\hline ERS-1 & C & ESA & 1992-1996 \\
\hline JERS-1 & $\mathrm{L}$ & JAXA & 1992-1998 \\
\hline RADARSAT-1 & C & CSA & 1995-2013 \\
\hline ERS-2 & C & ESA & 1996-2011 \\
\hline SRTM & $C, X$ & NASA & 2000 \\
\hline ENVISAT & C & ESA & 2002-2011 \\
\hline ALOS & $L$ & $J A X A$ & 2006-2011 \\
\hline RADARSAT-2 & C & CSA & 2007-present \\
\hline TerraSAR-X & $x$ & DLR & 2007-present \\
\hline COSMO-SkyMed & $x$ & ASI & 2007-present \\
\hline TanDEM-X & $x$ & DLR & 2010-present \\
\hline ALOS-2 & $L$ & JAXA & 2014-present \\
\hline Sentinel-1 & C & ESA & 2014-present \\
\hline SAOCOM & $L$ & CONAE/ASI & 2017-present \\
\hline NISAR & $L$ & NASA/ISRO & 2021 (planned) \\
\hline ALOS-4 & $\mathrm{L}$ & JAXA & 2022 (planned) \\
\hline Tandem-L & $L$ & DLR & (planned) \\
\hline
\end{tabular}

Ishitsuka et al. (2020) also investigated the postseismic deformation of the Kumamoto earthquakes, as Hashimoto (2020) did. They processed Sentinel-1 and ALOS-2 images to gain temporal resolution and detected deformation associated with groundwater movement. They interpreted postseismic subsidence which correlates with postseismic groundwater drawdown. They also detected seasonal deformation, which correlates with the seasonal variation of water level. The amplitude of seasonal deformation increased after the Kumamoto earthquake. These findings suggest that the Kumamoto earthquake changed aquifer permeability, compressibility, or both, leading to enhanced deformation associated with groundwater movement.

Fukushima et al. (2019) investigated another onshore earthquake, the 2017 Ormoc $\left(M_{\mathrm{w}}=6.5\right)$, on the creeping Philippine fault in Leyte island, the Philippines. They processed ALOS and ALOS-2 images to find that the Philippine fault is creeping with a rate of $33 \pm 11 \mathrm{~mm} /$ year in the northern and central part of the Leyte island except for the locked portion where the Ormoc earthquake took place. An investigation of teleseismic records of the 1947 earthquake $\left(M_{\mathrm{s}}=6.9\right)$ revealed that the Ormoc earthquake and the 1947 earthquake exhibit the repeating rupture within the same locked patch. They also inferred that the 1947 earthquake of $M_{\mathrm{s}}=6.9$ is nearly the maximum earthquake the Philippine fault can generate in the northern and central Leyte island. Their study demonstrates the utility of SAR images to assess large earthquakes along creeping faults.
InSAR is a powerful tool to investigate moderate-sized $(M<6.5)$ earthquakes when local and regional seismic data are not available. Ghayournajarkar and Fukushima (2020) demonstrated another example with the 2017 Sefid Sang, northern Iran, earthquake $\left(M_{\mathrm{w}}=6.1\right)$ from ALOS-2 and Sentinel-1 images. The observed displacement field fits well with both northeast- and southwest-dipping faults, but the aftershock distribution and orientation of active faults led them to conclude that the northeast-dipping fault is more favorable than the southwest-dipping fault. Their study demonstrates the utility of SAR images to investigate middle-sized earthquakes. Simultaneously, it demonstrates the difficulty in constraining which of two conjugate planes is responsible for the earthquake even with interferograms from both ascending and descending images.

Wang et al. (2019) and Narita et al. (2020) investigated volcano deformation. Wang et al. (2019) measured surface deformation near the vent of Asama Volcano, Japan, during its relatively dormant period (2014-2018). They employed not only ALOS-2 but also Sentinel-1 images to take advantage of more frequent acquisitions. Their time series analysis revealed surface deformation of up to $7 \mathrm{~mm} /$ year to the northeast and southeast of the summit. The surface deformation to the southeast of the summit is likely due to flank sliding, while the origin of that to the northeast of the summit is ambiguous. Although the area coincides with the lava deposit by a previous large eruption, thermal contraction is not responsible for this observed deformation because a theoretical consideration indicates the observed thermal contraction there should be negligible by now. The origin of the deformation there is either by flank sliding or due to hydrothermal activity. Flank sliding to the northeast of the summit should be northward, but the insensitivity to north-south displacements of spaceborne InSAR prevents the authors from confirming that the observed displacements there are due to flank sliding.

Narita et al. (2020) measured surface deformation between 2014 and 2018 from ALOS-2 and airborne PiSAR-L2 images. Utilizing airborne SAR images takes advantage of delineating arbitrary components of displacements, while interferograms from spaceborne SAR images are insensitive to north-south displacements because of the polar orbit of the satellite. The observed three-dimensional displacement field and its temporal evolution led Narita et al. (2020) to postulate two hydrothermal reservoirs at $\sim 150$ and $\sim 700 \mathrm{~m}$ below sea level, with an impermeable bed between them. They interpreted that accelerating flux of hydrothermal fluid from depth to the deeper reservoir led to accelerating flux of hydrothermal fluid from the deeper to shallower reservoir. They concluded that the pressurization of 
the shallower reservoir triggered a phreatic eruption in April 2018.

Various origins, including earthquake shaking and heavy rainfall, trigger landslides. SAR is a useful tool to detect and monitor landslides because of its high spatial resolution. Takada and Motono (2020) investigated details of a large landslide site at Mt. Onnebetsu-dake, northeastern Japan, in the last $\sim 25$ years from JERS1 , ALOS, and ALOS-2 images. The landslide velocity changes over time with a maximum of $60 \mathrm{~mm} /$ year of eastward velocity and $20 \mathrm{~mm} /$ year of subsidence between 2014 and 2017. They interpreted that this velocity increase is due to increased pore pressure resulting from elevated annual rainfall during that period. They also found a shorter-term increase of landslide velocity in August 2016, by heavy rainfall. These observations indicate that both long- and shortterm variations of rainfall affect the dynamics of landslides. The internal deformation within the landslide site indicates that the gravitational forces primarily drive the landslide.

While Takada and Motono (2020) focused on the dynamics of landslides, Ohki et al. (2020) focused on detecting landslides. They combined SAR polarimetry (PolSAR), InSAR, and Digital Elevation Model (DEM), to develop an algorithm to detect landslides. They applied their method to landslides by the 2017 heavy rainfall in northern Kyushu, Japan, and the 2018 Hokkaido Eastern Iburi, Japan, earthquake to find that polarimetric parameters, e.g., the alpha angle and Pauli components, are good indicators to discriminate damaged areas. They also found that supervised classification with PolSAR, InSAR, and DEM works well, although the classification accuracy depends on the training data's geological characteristics. These findings demonstrate the utility of SAR images to detect landslides quickly.

Recent global warming causes ground deformation due to excess melting of ground ice, and the processes to form subsequent terrain are called thermokarst. Abe et al. (2020) mapped subsidence due to thermokarst in Central Yakutia, Russia, with ALOS and ALOS-2 images. They detected a subsidence of 5-30 mm/year with seasonal variation in deforested areas, while the deformation in forested regions is negligible. This difference is consistent with the thermokarst dynamics through freezing and thawing. Also, the observation from the SAR images is consistent with field measurements and optical images. They found that L-band SAR images are useful in longterm monitoring permafrost areas because of persistent coherence.

Land subsidence of natural and anthropogenic origin, as well as global warming, is an issue that threatens human life. Herrera-García et al. (2021) recently reported that land subsidence would pose 635 million people at risk by 2040 . SAR is a powerful tool to detect and monitor land subsidence because of its high spatial resolution. Li et al. (2020) found from ALOS images that more than $122 \mathrm{~km}^{2}$ of the Pearl River Delta, southern China, subsided by more than $30 \mathrm{~mm} /$ year between 2006 and 2011 . In particular, the front part of the delta and the coastal area were subsiding by more than $50 \mathrm{~mm} /$ year. These observations led Li et al. (2020) to interpret that the subsidence is partly due to the thick, soft soil layer and partly due to human interference, such as reclamation, groundwater extraction, and urban construction.

This special issue demonstrates the utility of SAR images, L-band SAR images in particular, for various Earth Science applications including, but not limited to, earthquake and volcano deformation, landslide, glaciology, and land subsidence. In the next few years, the launch of new L-band satellites, including ALOS-4, NISAR, and Tandem-L, will give us a powerful new tool with which to make exciting discoveries, in particular by combining these L-band images with pre-existing $\mathrm{C}$ - and $\mathrm{X}$-band SAR images.

\begin{abstract}
Abbreviations
ALOS: Advanced Land Observing Satellite; ASI: Agenzia Spaziale Italiana (Italian Space Agency); CONAE: Comisión Nacional de Actividades Espaciales (National Space Activities Commission of Argentina); COSMO-SkyMed: Constellation of Small Satellites or Mediterraneanbasin Observation; CSA: Canadian Space Agency; DLR: Deutsches Zentrum für Luft- und Raumfahrt (German Aerospace Center); ENVISAT: Environmental Satellite; ERS: European Remote-Sensing Satellite; ESA: European Space Agency; InSAR: Synthetic Aperture Radar Interferometry; ISRO: Indian Space Research Organization; JAXA: Japan Aerospace Exploration Agency; NASA: National Aeronautics Space Administration; SAR: Synthetic Aperture Radar; TanDEM-X: TerraSAR add-on for Digital Elevation Measurement; US DoD: United States Department of Defense.
\end{abstract}

\section{Acknowledgements}

We thank authors and reviewers who contributed to organize this special issue. We also thank Editor-in-Chief Yasuo Ogawa for recommending to organize this special issue.

\section{Authors' contribution}

All authors served as guest editors for this special issue, YA being the lead guest editor. All authors read and approved the final manuscript.

\section{Ethical approval and consent to participate}

Not applicable.

\section{Consent for publication}

Not applicable.

\section{Competing interests}

The authors declare that they have no competing interests.

\footnotetext{
Author details

${ }^{1}$ Earthquake Research Institute, The University of Tokyo, Tokyo, Japan. 2 Department of Natural History Science, Hokkaido University, Sapporo, Japan. ${ }^{3}$ Remote Sensing Technology Department, German Aerospace Center, Weßling, Germany. ${ }^{4}$ Institut Des Sciences de La Terre, Université Grenoble Alpes, Grenoble, France. ${ }^{5}$ Japan Aerospace Exploration Agency, Chofu, Japan. ${ }^{6}$ COMET, School of Earth and Environment, University of Leeds, Leeds, UK.
} 
Received: 15 January 2021 Accepted: 15 January 2021

Published online: 23 February 2021

\section{References}

Abe T, Iwahana G, Efremov PV, Desyatkin AR, Kawamura T, Fedorov A, Zhegusov Y, Yanagiya K, Tadono T (2020) Surface displacement revealed by L-band InSAR analysis in the Mayya area, Central Yakutia, underlain by continuous permafrost. Earth Planets Space 72:138. https://doi. org/10.1186/s40623-020-01266-3

Fukushima Y, Hashimoto M, Miyazawa M, Uchida N, Taira T (2019) Surface creep rate distribution along the Philippine fault, Leyte Island, and possible repeating of Mw 65 earthquakes on an isolated locked patch. Earth Planets Space 71:118. https://doi.org/10.1186/s40623-019-1096-5

Fujiwara S, Nakano T, Morishita Y (2020) Detection of triggered shallow slips caused by large earthquakes using L-band SAR interferometry. Earth Planets Space 72:119. https://doi.org/10.1186/s40623-020-01239-6

Ghayournajarkar N, Fukushima Y (2020) Determination of the dipping direction of a blind reverse fault from InSAR: case study on the 2017 Sefid Sang earthquake, northeastern Iran. Earth Planets Space 72:64. https:// doi.org/10.1186/s40623-020-01190-6

Hashimoto M (2020) Postseismic deformation following the 2016 Kumamoto earthquake detected by ALOS-2/PALSAR-2. Earth Planets Space 72:154. https://doi.org/10.1186/s40623-020-01285-0

Herrera-García G, Ezquerro P, Tomás R, Béjar-Pizarro M, López-Vinielles J, Rossi M, Mateos RM, Carreón-Freyre D, Lambert J, Teatini P, Cabrai-Cano E, Erkens G, Galloway D, Hung W-C, Kakar N, Sneed M, Tosi L, Wang H, Ye S (2021) Mapping the global threat of land subsidence. Science 371:34-36. https://doi.org/10.1126/science.abb8549

Ishitsuka K, Tsuji T, Lin W, Kagabu M, Shimada J (2020) Seasonal and transient surface displacements in the Kumamoto area, Japan, associated with the
2016 Kumamoto earthquake: implications for seismic-induced groundwater level change. Earth Planets Space 72:144. https://doi.org/10.1186/ s40623-020-01275-2

Li G, Feng G, Xiong Z, Liu Q, Xie R, Zhu X, Luo S, Du Y (2020) Surface deformation evolution in the Pearl River Delta between 2006 and 2011 derived from the ALOS1/PALSAR images. Earth Planets Space 72:179. https://doi. org/10.1186/s40623-020-01310-2

Massoneet D, Rossi M, Camona C, Adragna F, Peltzer G, Feigl K, Rabaute T (1993) The displacement field of the Landers earthquake mapped by radar interferometry. Nature 364:138-142. https://doi.org/10.1038/36413 $8 \mathrm{aO}$

Narita S, Ozawa T, Aoki Y, Shimada M, Furuya M, Takada Y, Murakami M (2020) Precursory ground deformation of the 2018 phreatic eruption on IwoYama volcano, revealed by four-dimensional joint analysis of airborne and spaceborne InSAR. Earth Planets Space 72:145. https://doi.org/10.1186/ s40623-020-01280-5

Ohki M, Abe T, Tadono T, Shimada M (2020) Landslide detection in mountainous forest areas using polarimetry and interferometric coherence. Earth Planets Space 72:67. https://doi.org/10.1186/s40623-020-01191-5

Takada Y, Motono G (2020) Spatiotemporal behavior of a large-scale landslide of Mt Onnebetsu-dake, Japan, detected by three L-band SAR satellites. Earth Planets Space 72:1331. https://doi.org/10.1186/s40623-020-01265-4

Wang X, Aoki Y, Chen J (2019) Surface deformation of Asama Volcano, Japan, detected by time series InSAR combining persistent distributed scatterers, 2014-2018. Earth Planets Space 71:121. https://doi.org/10.1186/ s40623-019-1104-9

\section{Publisher's Note}

Springer Nature remains neutral with regard to jurisdictional claims in published maps and institutional affiliations.

\section{Submit your manuscript to a SpringerOpen ${ }^{\circ}$ journal and benefit from:}

- Convenient online submission

- Rigorous peer review

- Open access: articles freely available online

- High visibility within the field

- Retaining the copyright to your article

Submit your next manuscript at $\boldsymbol{\nabla}$ springeropen.com 